\title{
Role of hepatitis C virus in chronic liver disease occurring after orthotopic liver transplantation
}

\author{
Maria Pastore, Marc Willems, Chantal Cornu, Jean Paul Buts, R Reding, \\ J de Ville de Goyet, J Rahier, Jean Bernard Otte, Sing Hien Yap, Etienne Marc Sokal
}

Abstract

Paediatric orthotopic liver transplant recipients may develop chronic hepatitis after surgery. To investigate the role of hepatitis $\mathbf{C}$ virus in this pathology a cohort of 249 paediatric orthotopic liver transplant recipients was studied. Sixteen children $(6 \cdot 4 \%)$ were found to have chronic hepatitis $C$ virus hepatitis after orthotopic liver transplantation. All but one of them had serum transaminase values which were persistently raised two to eight times the upper limit of normal. Thirteen were positive for both serology and serum hepatitis $C$ virus RNA. Serum hepatitis C virus RNA detection occurred five to 33 months before hepatitis $C$ virus antibodies. Liver tissue hepatitis $C$ virus RNA and hepatitis $C$ virus core antigen were detected in five. In one patient, tissue hepatitis $C$ virus core antigen was detected when other tests for hepatitis $C$ were negative. Two patients had positive human cytomegalovirus serum antibodies and RNA before transplantation. Although serum hepatitis $C$ virus RNA was not detected after transplantation, serum enzyme immunosorbent assay and tissue core antigen were still detectable in both patients. In another child, serum hepatitis $C$ virus RNA was positive and hepatitis $C$ virus core antigen was found on a liver biopsy specimen but antihepatitis $C$ virus antibodies were negative as well as liver hepatitis C virus RNA. No patient developed severe liver disease or cirrhosis during a follow up of up to 72 months. It is concluded that hepatitis $C$ virus is a significant cause of morbidity after paediatric orthotopic liver transplantation. Diagnosis cannot rely on serological testing only. The patients remained stable on follow up, but longer prospective histological studies remain necessary to establish prognosis.

(Arch Dis Child 1995; 72: 403-407)

Keywords: hepatitis $\mathrm{C}$ virus, liver disease, liver transplantation.

and Pancreatic

Diseases, Catholic

University of Leuven,

Leuven

M Willems

S H Yap

Correspondence to: Dr Etienne M Sokal Cliniques St-Luc, Catholic University of Louvain, 10 Avenue Hippocrate, B-1200 Brussels, Belgium.

Accepted 3 January 1995 cern is hepatitis $\mathbf{C}$ which is characterised by a high propensity to chronicity and may lead to severe damage in the liver graft. In contrast to adult recipients who are commonly infected by hepatitis $\mathrm{C}$ virus before transplantation, ${ }^{3-6}$ children are more likely to contract hepatitis $\mathrm{C}$ virus during or after the transplant procedure itself. ${ }^{7}$ The pathogenicity and natural history of hepatitis $C$ acquired on or after transplantation in childhood may not necessarily mimic recurrence of hepatitis $C$ virus infection as observed in adult liver transplant recipients.

In the present series, we analyse the prevalence of hepatitis $C$ virus infection in a cohort of 249 paediatric liver transplant recipients, and report our experience of hepatitis $C$ virus antibody and hepatitis $C$ virus genome detection and the natural history of this infection in liver transplantation recipients in childhood.

\section{Patients and methods}

PATIENTS

Between March 1984 and September 1993, orthotopic liver transplantation was performed in 314 children at our centre. The present study includes 249 of these $314(79.3 \%)$ children who have been regularly screened for the presence of hepatitis $\mathrm{C}$ virus antibodies using second and third generation antihepatitis $C$ virus (EIAs). The screening took place at each major check up performed on the patients, that is three, six, and 12 months after transplant and yearly thereafter, starting with the availability of tests for hepatitis $C$ virus in January 1990. A minimum of three hepatitis C virus tests were performed in each patient, and the minimal interval between the first and last investigation was six months. A total of 151 patients had transplant after January 1990 and 98 before. Blood and organ donors were also screened for antihepatitis $\mathrm{C}$ virus antibodies from that date. Sixty five $(20.7 \%)$ children were not included in this study because they had missed one or more major follow up visits and/or hepatitis $C$ virus serum marker determination.

Liver biopsy and biochemical data were obtained in all patients at six and 12 months after transplant and thereafter every year. In addition, liver biopsies were performed if abnormal liver function tests were present. In patients with abnormal liver histology or biochemical tests, additional serum samples were tested for antihepatitis $C$ virus by third generation recombinant immunoblot assay (RIBA3.0) and for hepatitis C virus RNA by polymerase chain reaction (PCR) (see laboratory techniques). In seven out of 16 children, a well preserved frozen biopsy sample obtained at the time of the liver enzyme abnormalities 
was available for hepatitis $C$ virus RNA and hepatitis $\mathrm{C}$ virus antigen detection, using a new immunohistochemical assay, as described elsewhere. ${ }^{8}$ Liver tissue hepatitis $\mathrm{C}$ virus RNA was also detected by the PCR technique.

\section{LABORATORY TECHNIQUES}

Serum samples were stored at $-70^{\circ} \mathrm{C}$ until used for testing. Antihepatitis $\mathrm{C}$ virus antibodies were detected with second or third generation enzyme immunosorbent assay (EIA) (screening and confirmatory assay (Ortho Diagnostic Systems). These tests were performed according to the manufacturer's recommendations. In the third generation EIA (Ortho), an additional recombinant antigen NS5 has been added to the other recombinant antigens (core, C33c, C110-3) used in the second generation assay.

In the third generation RIBA test (RIBA3.0), the hepatitis $C$ virus antigens, immobilised on nitrocellulose strips, are either recombinant proteins (C33c and NS5) or synthetic peptides (c100p and $c 22 p)$. The results, expressed in accordance with the rating system (from $1+$ to $4+$ ) proposed by the manufacturer, were defined as positive when reactive for at least two antigens and indeterminate when positive for only one antigen.

Hepatitis C virus RNA was extracted from $50 \mu l$ of serum sample using the acid guanidinium thiocyanate-phenol-chloroform method. ${ }^{9}$ Each serum sample was coextracted with one $\mathrm{H} 20$ sample used as negative control. The reverse transcription and nested PCR steps were done using primer pairs corresponding to the highly conserved $5^{\prime}$ noncoding region of the viral genome. ${ }^{10}$ The specificity of the PCR products was confirmed by Southern blot hybridisation under stringent conditions with an internal oligonucleotide probe (position from -185 to -148 ) enzymatically labelled with digoxigenin using DIG-System (oligonucleotide 3'-end labelling and detection kits; Boerhinger Mannheim). Results were recorded only if the samples and the negative and positive controls were reproducible in at least two independent experiments.

Serum aspartate and alanine aminotransferases activities were determined at $37^{\circ} \mathrm{C}$ according to the Deutsche Gesellschäft für Klinische Chemie method on the Hitachi 737 analyser.

Hepatitis C virus RNA was detected in liver tissue using a previously described reverse transcription PCR assay with primers derived from the highly conserved ' 5 ' non-coding region (UTR) of the viral genome. ${ }^{11}$ Enhanced detection of hepatitis $C$ virus RNA was found in some samples using other $5^{\prime}$ sense primers (outer sense primers: GTATCTCGAGGCGACACTCCACCATAGAT $=$ position -333 to -305 of $5^{\prime}$ UTR and inner sense primers: CCACCATAGATCTCTCCCCTGT $=$ position -315 to -294 of $5^{\prime}$ non-coding region according to Han et al and Garson et al. ${ }^{12} 13$

Hepatitis $C$ virus antigen in liver biopsy samples of transplanted patients was detected immunohistochemically using a specific monoclonal antibody (1F-2) directed against a synthetic core peptide, as described elsewhere. ${ }^{8}$

\section{LIVER HISTOLOGY}

The histological diagnosis of hepatitis was based on the presence of portal and/or parenchyma mononuclear infiltration and isolated hepatocyte necrosis as evidenced by acidophilic bodies. Hepatitis was classified as chronic if the changes were present for at least six months as determined clinically or histologically. Chronic liver damage was further classified as chronic active hepatitis, chronic persistent hepatitis, and chronic lobular hepatitis. For a diagnosis of chronic active hepatitis, a portal mononuclear infiltrate with piecemeal necrosis and disruption of the limiting plate by inflammatory cells was necessary. Chronic persistent hepatitis was characterised by expansion of the portal zone by mononuclear cells, with some fibrosis. Chronic lobular hepatitis was diagnosed when predominant intralobular inflammation with individual cell necrosis was found.

CRITERIA FOR DIAGNOSIS OF HEPATITIS C VIRUS INFECTION

Hepatitis $C$ virus infection was established by using at least two of the following criteria: (1) positive second or third generation EIA test with positive RIBA3.0; (2) positive serum hepatitis C virus RNA; or (3) positive liver hepatitis $C$ virus RNA with or without positive hepatitis $C$ virus antigen in liver tissue.

\section{Results}

LABORATORY DATA

Among 249 patients, 21 (8.4\%) children had at least one positive test for hepatitis $\mathrm{C}$ virus infection. None of them had positive serological and/or liver tissue markers for hepatitis $B$ virus infection.

In five patients, a positive second or third generation antihepatitis C virus EIA, was not confirmed by RIBA3.0 and hepatitis C virus RNA was not found in their serum. A slight increase of serum transaminases and minimal histological signs of non-specific hepatitis were demonstrated in four out of these five patients, while one patient had normal liver function tests and normal liver histology. Liver tissue was not available for hepatitis $C$ virus RNA and hepatitis $C$ virus antigen detection in these patients. None of these five patients displayed hypergammaglobulinaemia, a factor which is known to give false positive results in antihepatitis $C$ virus EIAs. Because of uncertain diagnosis, these patients were excluded from the hepatitis $\mathrm{C}$ virus series. In the remaining 16 children $(6.4 \%)$ a diagnosis of hepatitis $C$ virus infection was firmly established. Their pretransplant diagnoses were as follows: extrahepatic biliary atresia (8), Wilson's disease (3), congenital hepatic fibrosis (1) Byler's disease (1), Alagille's syndrome (1), non-A, non-B 
fulminant hepatitis (1), and cryptogenic cirrhosis (1). The mean follow up period after transplant in this group was $\mathbf{5 7}$ months (range: 18-87 months).

Eleven patients belonged to the subgroup of 98 who underwent orthotopic liver transplantation before screening of blood products and donor organs for hepatitis $C$ virus infection $(11 / 98=11 \cdot 2 \%)$. Their pretransplant hepatitis $\mathrm{C}$ virus status was unknown. The five remaining patients had orthotopic liver transplantation performed after the donor and recipient screening tests for hepatitis $\mathrm{C}$ virus became available $(5 / 151=3 \cdot 3 \%)$. All five donors had no hepatitis $C$ virus antibodies. The pretransplant hepatitis $C$ virus status of these five patients was: three patients were antihepatitis $C$ virus negative (second and third generation. EIA and RIBA3.0 test) with undetectable serum hepatitis $C$ virus RNA levels and two were positive for all these serological assay (EIAs, RIBA3.0, and PCR). After transplant 13 of 16 patients were found to be positive for antihepatitis $C$ virus antibodies detected by EIA and RIBA tests and for serum hepatitis $C$ virus RNA. In addition, in five of these 13 patients, liver biopsy specimens were tested for hepatitis $C$ virus RNA and hepatitis $C$ virus antigen and were found to be positive for both of them. The two patients who were known to be hepatitis $C$ virus antibody and serum hepatitis $C$ virus RNA positive before transplantation had no more detectable hepatitis $\mathrm{C}$ virus RNA in serum and liver after transplantation, but they remained antihepatitis $C$ virus positive (second and third generation EIA) with an indeterminate RIBA3.0 test. Hepatitis $C$ virus antigen was still found in their liver biopsy specimens (table). In the patient with fulminant hepatitis, serum hepatitis $C$ virus RNA was positive on two subsequent determinations but thereafter it became undetectable. Hepatitis C virus antibodies were always negative using EIAs and RIBA3.0 test and no hepatitis $C$ virus RNA was found in liver tissue. However, hepatitis $\mathrm{C}$ virus antigen was positive in liver tissue (table).

In five children, serum hepatitis $C$ virus RNA preceded the appearance of hepatitis $C$ virus antibodies. the mean delay of seroconversion was about 20 months (range 5-33 months). All but one hepatitis $C$ virus infected child had persistently raised transaminases fluctuating from twice to eight times the upper normal limit.

LIVER HISTOLOGY

Fifteen of 16 patients infected with hepatitis $C$

Markers of hepatitis $C$ virus infection in 21 transplanted children

\begin{tabular}{|c|c|c|c|c|c|}
\hline \multirow{2}{*}{$\begin{array}{l}\text { No of } \\
\text { patients }\end{array}$} & \multicolumn{2}{|c|}{ Antihepatitis $C$ virus } & \multicolumn{2}{|c|}{ Hepatitis $C$ virus $R N A$} & \multirow{2}{*}{$\begin{array}{l}\text { Hepatitis } C \\
\text { virus antigen } \\
\text { in liver }\end{array}$} \\
\hline & $E L A$ & $R I B A$ & Serum & Liver & \\
\hline $\begin{array}{c}13 \\
2 \\
1 \\
5^{\star}\end{array}$ & $\begin{array}{l}+ \\
+ \\
+ \\
+\end{array}$ & $\begin{array}{l}+ \\
\text { Indeterminate } \\
- \\
-\end{array}$ & $\begin{array}{l}+ \\
+ \\
+ \\
-\end{array}$ & $\begin{array}{l}+(5) \\
- \\
\overline{N P}\end{array}$ & $\begin{array}{l}+(5) \\
+ \\
+ \\
\text { NP }\end{array}$ \\
\hline
\end{tabular}

*Patients not included in the group with chronic hepatitis C. †Positive on two occasions and persistently negative thereafter
$\mathrm{NP}=$ not performed. virus had a histological picture compatible with the diagnosis of chronic hepatitis $\mathrm{C}$, and one had normal histology. Chronic persistent hepatitis was detected in 10 patients and chronic active hepatitis in one. In these 11 patients, liver histology remained unchanged during follow up and no aggravation of inflammation nor fibrosis was noticed. The four remaining patients had chronic lobular hepatitis, of whom two progressed towards increasing lobular inflammation and portal involvement, without fibrosis.

\section{Discussion}

The $6.4 \%$ prevalence of hepatitis $C$ virus infection reported in our paediatric liver transplant series is similar to that reported from the Cochin Bicêtre paediatric series, ${ }^{7}$ while prevalence as high as $35 \%$ has been reported after orthotopic liver transplantation in previously hepatitis $\mathrm{C}$ virus negative adult recipients. ${ }^{14}$

All our patients showed to variable degrees histological features compatible with the diagnosis of chronic hepatitis $\mathrm{C}$. The histological aspect of chronic hepatitis $C$ was not specific in our experience and this is generally explained by immunosuppression itself, which may alter the histological appearance of viral hepatitis after transplantation. ${ }^{15}$ In addition associated problems may interfere, such as rejection, cytomegalovirus related hepatitis, ischaemic injury, drug toxicity, and vascular and biliary problems. ${ }^{15} 16$ Although none of the patients had fibrosis nor cirrhosis, a longer follow up is needed to establish long term prognosis of this slowly progressive disease, whose natural history in paediatric patients who have not been transplanted also remains poorly documented. It has been shown that only $10 \%$ of children infected with hepatitis $\mathrm{C}$ virus but not transplanted achieve sustained biochemical remission and that severe active hepatitis or even cirrhosis may develop within six years of infection. ${ }^{17} \mathrm{No}$ case of acute graft failure or rapidly progressive hepatitis was observed in our series, in agreement with other paediatric and adult series. ${ }^{718}$ Development of cirrhosis is described in adult patients, and $50 \%$ of adult patients may have chronic active hepatitis two years after the initial acute hepatitis $C$ virus hepatitis. ${ }^{18}$ Newly acquired hepatitis $C$ seems to have a slower progress after transplantation than recurrent hepatitis $C$ in adult patients. ${ }^{18}$ Even if some children may have been infected by hepatitis $\mathrm{C}$ virus before transplantation, hepatitis $\mathrm{C}$ was usually not the original cause of liver disease, and patients may be infected at the time of transplantation or shortly after. Pretransplant hepatitis C virus infection was diagnosed in two of our patients, one of them having cryptogenic cirrhosis compatible with hepatitis $C$ virus infection as the primary cause of liver disease.

Systematic screening of blood donors for hepatitis $\mathrm{C}$ virus has reduced but not eliminated the risk of hepatitis $\mathrm{C}$ virus infection acquired after transfusion. ${ }^{19}$ For solid organ 
transplantation, however, hepatitis $\mathrm{C}$ virus may also be transmitted by the graft. ${ }^{32021}$ This mode of transmission may have contributed to de novo hepatitis $\mathrm{C}$ virus infections in our patients, although we cannot exclude reinfection of their liver by pre-existing hepatitis $\mathrm{C}$ virus infection. They may also become infected by blood transfusions administered during and after orthotopic liver transplantation. This stresses the importance of testing organ donors for the presence of hepatitis C virus RNA both in serum and graft, a time consuming test which is unfortunately not available routinely in laboratories. $^{21} 22$

A complete concordance of tests for hepatitis C virus (EIA, RIBA, and serum hepatitis $C$ virus RNA) was observed in 13 out of $16(81 \%)$ transplanted children. Two patients were already positive for hepatitis C virus markers before transplant; antihepatitis $C$ virus antibodies remained positive after orthotopic liver transplantation, but serum and liver tissue hepatitis $C$ virus RNA were undetectable. Positive hepatitis $\mathrm{C}$ virus antigens in these grafts suggest, however, that infection recurred after transplant unless the donors were themselves infected with hepatitis C virus. One of these two patients had normal liver function tests and normal histology during follow up (18 months), and hepatitis C virus antigen was the only evidence of hepatitis $C$ virus infection after transplant.

The high sensitivity of the hepatitis $C$ virus antigen detection assay was further demonstrated in the patient with fulminant hepatitis who had serum hepatitis $C$ virus RNA detected on two occasions with negative serology. Positive liver hepatitis $\mathrm{C}$ virus antigen remained the only positive test in this patient whose liver histology after transplant and biochemical profile was consistent with chronic hepatitis $\mathrm{C}$.

An important finding in our series is the frequent negative hepatitis $C$ virus serology in our patient despite proved hepatitis $C$ virus infection (positive serum or tissue hepatitis $C$ virus RNA), with seroconversion delay as long as 33 months after infection. ${ }^{320}$ The possibility of false negative results in antihepatitis $C$ virus EIAs and RIBA tests has been demonstrated in transplant patients with positive serum hepatitis $C$ virus RNA suggesting that immunosuppressive treatment might delay the appearance of serum antibodies against hepatitis $\mathrm{C}$ virus. ${ }^{23}$

This and the intermittent viraemia of hepatitis $C$ virus may hamper the positive diagnosis of hepatitis $C$ virus infection in many patients. Non-detection of serum hepatitis $C$ virus RNA can be due to low concentration of circulating virions or intermittent viraemia.

In five of 20 patients, hepatitis $C$ virus antibodies were found using a second or third generation EIA, but no hepatitis C virus RNA was found in serum and RIBA3.0 was negative. These false positive results in antihepatitis $C$ virus assays have been previously reported ${ }^{2324}$ and may lead to overestimation of the prevalence of hepatitis $C$ virus infection. RIBA negativity does exclude hepatitis $C$ virus infection. 2526

\section{Conclusion}

Systematic screening of patients and donors for hepatitis $C$ virus is mandatory, before and after transplantation. Negative antihepatitis C virus assays do not exclude hepatitis $C$ virus infection, and positive tests must be confirmed by RIBA test and detection of serum hepatitis $C$ virus RNA. Whenever possible, hepatitis $C$ virus RNA must be looked for in liver tissue. The detection of hepatitis $C$ virus antigen seems very promising as a tool for diagnosis of hepatitis $C$ virus infection in children who have had orthotopic liver transplantation. Donor serum and liver hepatitis C virus RNA testing, and perhaps donor liver hepatitis $C$ virus antigen testing, may decrease the prevalence of de novo hepatitis $\mathrm{C}$ virus infection in transplanted children. Short term prognosis of the transplant child is not affected by hepatitis C virus infection. We did not observe rapid progressive hepatitis, nor severe liver damage on follow up in this series, but long term prospective histological studies are needed to determine the natural course of hepatitis $C$ virus infection in these patients.

1 Cames B, Rahier J, Burtomboy G, et al. Acute adenovirus hepatitis in liver transplant recipients. $\mathcal{F}$ Pediatr 1992; 120: 33-7.

2 Sokal EM, Caragiozoglou T, Lamy M, Reding R, Otte JB. Epstein-Barr virus serology and Epstein-Barr virusassociated lymphoproliferative disorders in pediatric liver transplant recipients. Transplantation 1993; 56: 1394-8.

3 Martin P, Munoz SJ, Di Bisceglie AM, et al. Recurrence of hepatitis C virus infection after orthotopic liver transplantation. Hepatology 1991; 13: 719-21.

4 Shah S, Demetris AJ, Gavaler JS, Todo S, Starzl TE, Van Thiel DH. Incidence, prevalence and clinical course of hepatitis $C$ following liver transplantation. Gastroenterology 1992; 103: 323-9.

5 Hart J, Busuttil RW, Lewin KJ. Disease recurrence following liver transplantation. Am $\mathcal{F}$ Surg Pathol 1990; 14 (suppl

6 Volker K, Bauditz J, Lobeck H, et al. Hepatitis C virus reinfection in allografts after orthotopic liver transplantation. Hepatology 1992; 16: 1137-43.

7 Dussaix E, de Paillette L, Laurent-Puig P, et al. Hepatitis C virus infection in pediatric liver transplantation. Transplantation 1993; 55: 795-8.

8 Yap SH, Willems J, Van den Oord J, et al. Detection of hepatitis C virus (HCV) antigen by immuno-histochemical staining. A histological marker of HCV infection. $\mathcal{H}$ Hepatol 1994; 20: 275-81.

9 Chomczynski P, Sacchi N. Single step method of RNA isolation by acid guanidinium thiocyanate-phenochloroform extraction. Anal Biochem 1987; 162: 156-9.

10 Imberti L, Cariani E, Bettinardi A, Zonaro A, Albertini A, Primi D. An immunoassay for specific amplified HCV Primi D. An immunoassay for specific amp

11 Willems M, De Jong G, Moshage H, et al. Surrogate markers are not useful for identification of HCV carriers in chronic hemodialysis patients. F Med Virol 1991; 35 303-6.

12 Han JH, Shyamala V, Richman KH, et al. Characterization of the terminal region of hepatitis $C$ viral RNA: identification of conserved sequences in the $5^{\prime}$ untrans lated region and poly (A) tails at the $3^{\prime}$ end. Proc Natl Acad Sci USA 1991; 88: 1711-5.

13 Garson JA, Ring CJA, Tuke PW. Enhanced detection by PCR of hepatitis C virus RNA Lancet 1990; 336: 878-9.

14 Wright $\mathrm{TL}$, Donegan E, Hsu H, et al. Recurrent and acquired hepatitis $\mathrm{C}$ viral infection in liver transplant recipients. Gastroenterology 1992; 103: 317-22.

15 Ferell L, Wright TL, Roberts J, Ascher NL, Lake J. Hepatitis $C$ viral infection in liver transplant recipients. Hepatology 1992; 16: 865-76.

16 Sokal EM, Veyckemans F, de Ville de Goyet J, et al. Liver transplantation in children less than one year of age. f Pediatr 1990; 117: 205-10.

17 Bortolotti F, Jara P, Diaz C, et al. Post-transfusion and community acquired hepatitis $C$ in childhood. $₹$ Pediatr Gunity acquired hepatitis $C$ in child

18 Féray C, Gigou M, Samuel D, et al. The course of hepatitis $\mathrm{C}$ virus infection after liver transplantation. Hepatology 994; 20: 1137-43.

19 Donahue JG, Munoz A, Ness PM, et al. The declining risk of post-transfusion hepatitis $\mathrm{C}$ virus infection. $N$ Engl f Med 1992; 327: 369-73.

20 Dodd RY. The risk of transfusion-transmitted infection. $N$ Engl $\mathcal{F}$ Med 1992; 327: 419-20. 
21 Pereira BJG, Milford EL, Kirkman RL, et al. Prevalence of hepatitis $C$ virus $R N A$ in organ donors positive for hepatitis $\mathrm{C}$ antibody and in the recipients of their organs. N Engl F Med 1992; 327: 910-5.

22 Pereira BJG, Milford EL, Kirkman RL, Levey AS Transmission of hepatitis $\mathrm{C}$ virus by organ transplantation. N Engl f Med 1991; 325: 454-60.

23 Poterucha J, Rakela J, Lumeng L, Lee CH, Taswell HF, Wiesner RH. Diagnosis of chronic hepatitis C after liver transplantation by the detection of viral sequences with polymerase chain reaction. Hepatology 1992; 15: 42-5. 24 McFarlane IG, Smith HM, Johnson PF, Bray GP, Vergani
D, Williams $R$. Hepatitis $C$ virus antibodies in chronic active hepatitis. Pathogenetic factor or false positive results? Lancet 1990; 335: 754-7.

25 Lazizi Y, Elfassi E, Pillot J. Detection of hepatitis C virus sequences in sera with controversial serology by nested polymerase chain reaction. f Clin Microbiol 1992; 30: 931-4.

26 Bukh J, Wantzin P, Krogsgaard K. High prevalence of hepatitis $\mathrm{C}$ virus HCV RNA in dialysis patients: failure of commercially available antibody tests to identify a significant number of patients with $\mathrm{HCV}$ infection. F Infect Dis 1993; 168: 1343-8.

\section{The psychology of smallness}

One reason given for offering growth hormone treatment to short children who are not demonstrably growth hormone deficient is that it might save them psychological trauma. Workers in Buffalo, New York State (David E Sandberg and colleagues, Pediatrics 1994; 94: 832-40) have measured psychosocial functioning in their short patients.

The study involved 258 children and adolescents ( 180 boys, 78 girls) aged 4 to 18 years referred to a paediatric endocrinology clinic because of short stature (height less than 5th centile). Their height $Z$ (SD) scores were: mean $-2 \cdot 3$, SD $0 \cdot 5$, range $-4 \cdot 0$ to $-1 \cdot 6$. Fifty four per cent had 'normal variant' short stature, 33\% had various diagnoses including growth hormone deficiency (14\%), undernutrition, skeletal dysplasia and chromosomal abnormality, and the remaining $13 \%$ had short stature of undetermined cause. Psychosocial assessments were made using three questionnaires; the child behaviour checklist (CBCL) completed by parents, and the youth self report and self perception profile, both completed by the patients.

Boys in the study were described by their parents as being less socially competent and showing more behavioural and emotional problems than the CBCL norms and the boys described themselves as being less socially active but had normal estimates of their own abilities and self worth. Nevertheless the psychosocial morbidity in boys was not great and the findings in girls were normal. Neither the degree of short stature nor its cause was significantly related to psychosocial functioning.

The authors conclude that psychosocial malfunction is not a reason for growth hormone treatment of most children with normal variant short stature. 